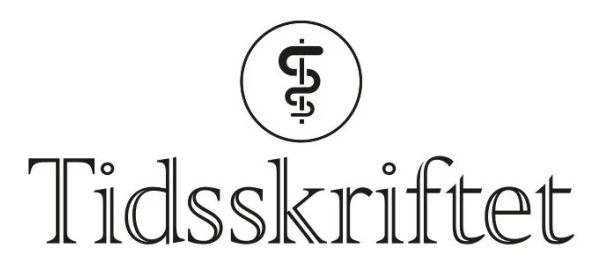

DEN NORSKE LEGEFORENING

\title{
Svimmelhet på dagsordenen
}

\author{
ANMELDELSER
}

UNN LJØSTAD

Overlege, Nevrologisk avdeling Sørlandet sykehus, Kristiansand

Kjersti Wilhelmsen, Anne Kari Skøien, Anne-Lise Tamber, red.

Fra svimmelhet til balanse

Vestibulære sykdommer. Teori, unders $\varnothing$ kelse og rehabilitering. 272 s, tab, ill. Bergen: Fagbokforlaget, 2019. Pris NOK 599

ISBN 978-82-450-1227-9

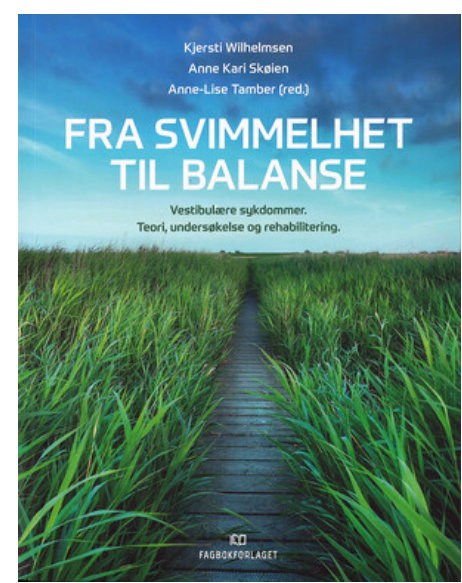

Redaktørene ønsker å sette svimmelhet på dagsordenen og har som mål å lære helsepersonell om diagnostikk og behandling av vestibulære sykdommer.

I første del gis en teoretisk innføring i hvordan svimmelhet kan oppstå og hvordan kompensering er mulig dersom deler av balansesystemet svikter. Andre del handler om klinisk tilnærming til svimle pasienter ved hjelp av fokusert anamneseopptak, klinisk testing og tilpasset behandling. Diagnostiske tester og terapeutiske manøvrer er forklart med fine fargeillustrasjoner, og hovedpunktene er oppsummert i tabeller og rammer.

I tredje del presenteres en del kliniske erfaringer og eksempler på ulike aspekter ved vestibulær rehabilitering. Fjerde og siste del er en samling av nyttige spørreskjema, skåringskjema og eksempler på enkle egentreningsprogram. 
Boka kan leses fra perm til perm og vil da utvilsomt gi en god forståelse av årsaker til svimmelhet, og diagnostikk og behandling ved vestibulære tilstander, men den vil trolig også fungere godt som problembasert oppslagsverk i en travel klinisk hverdag. At redaktørene er fysioterapeuter, gjenspeiles i et hovedfokus på vedvarende svimmelhet og vestibulær rehabilitering - kanskje det mest forsømte området i

svimmelhetshåndteringen. Nyoppstått svimmelhet er også grundig og fint omtalt, men en tydelig oppsummering av symptomer og funn som bør medføre umiddelbar eller rask henvisning til sykehus, kunne vært nyttig.

Alt i alt er dette et nyttig og pedagogisk oppslagsverk. Boka handler om et utbredt symptom som kan gi betydelig funksjonssvikt, men som ofte kan bedres med riktig og årsaksspesifikk tilnærming. Les og lær!

Publisert: 14. februar 2022. Tidsskr Nor Legeforen. DOI: 10.4045/tidsskr.21.0805

(C) Tidsskrift for Den norske legeforening 2023. Lastet ned fra tidsskriftet.no 26. april 2023. 